УДК 325.111

DOI: https://doi.org/10.26642/jen-2019-4(90)-207-213

Л.В. Сергієнко, к.н.держ.упр. К.М. Войціцька, аспір.

Державний університет «Житомирська політехніка»

\title{
Сутність, особливості та стадії розвитку урбанізації
}

\begin{abstract}
Розвиток людської ичивілізаиії, у історичному контексті, має ряд характеристик незалежно від періоду, серед яких окреме місие необхідно відвести потребі людства у групуванні та об'єднанні на певній території. 3 часом форми об'єднання людей змінювалися, проте однією із передумов появи міст чи інших населених пунктів є економічний, сочіальний розвиток даної території. 3 іншого боку, поява людей та їх синергія, а також використання потенціалу людських ресурсів на окремій території обумовлюють ї̈ сочіально-економічний розвиток, а також розвиток у інших сферах. Проблематика урбанізованості територій, пошук механізмів публічного управління щчодо забезпечення прав, свобод, законних інтересів людей на даній території, а також дослідження векторів формування та реалізації публічної політики сталого розвитку, в умовах урбанізації, $\epsilon$ важливими завданнями, щуо постають не лише перед вітчизняними органами державної влади та політиками, але $i$ знаходяться у фокусі функціонування суб'єктів публічного управління зарубіжних країн, експертів та міжнародних організацій. Основою розробки теоретико-методологічних засад публічного управління $\epsilon$ використання єдиних підходів до визначення понять та категорій, а зважаючи на складність урбанізації як явища та прояв його у різних сферах життєдіяльності, було вивчено та узагальнено підходи вітчизняних $і$ зарубіжних вчених до трактування категорії «урбанізація». Запропоновано авторське тлумачення поняття «урбанізація» з позицій цілей регіонального розвитку. Встановлено, щуо урбанізація є складним глобальним прочесом, який впливає на соціально-економічний розвиток регіонів, а також визначено ї̈ характерні особливості. Ідентифіковано стадї розвитку урбанізащії та здійснено їх характеристику. Досліджено стан урбанізаційного процесу в Україні та встановлено, щзо на сьогоднішній день більшість регіонів $\epsilon$ слаборозвиненими, а урбанізованість територій Украӥни є нерівномірною, тому використання системи публічного управління та публічно-управлінського інструментарію у даному напрямі $\epsilon$ важливим завданням, щуо актуалізується необхідністю досягнення Цілей сталого розвитку.

Ключові слова: урбанізачія; урбанізачійний прочес; місто; регіон; сочіально-економічний розвиток.
\end{abstract}

Актуальність теми. Сучасний етап розвитку суспільства характеризується високим рівнем урбанізованості території. 3 одного боку, урбанізація є невід'ємною частиною розвитку суспільства, а 3 другого боку, розвиток суспільства обумовлює розвиток урбанізаційних процесів. Визнані міжнародні організації, такі як Світовий банк, ООН, Міжнародний банк реконструкції та розвитку, досліджуючи урбанізаційну проблематику, наголошують на тому, що майбутнє цивілізації - це міста та їх постійне зростання. За таких умов, серед завдань функціонування системи публічного управління та адміністрування постають нові не лише завдання, але і з'являються нові інструменти та інноваційні підходи щодо забезпечення соціально-економічного розвитку. Беззаперечним $є$ і буде залишатися той факт, що соціально-економічний розвиток регіонів залежить не тільки від кліматичних умов, ресурсозабезпеченості, виробничих потужностей, транспортної інфраструктури, а й від рівня урбанізованості тієї чи іншої території, адже людські ресурси та їх потенціал, в умовах Четвертої промислової революції Industry 4.0, є визначальним фактором забезпечення науково-технічного прогресу, створення інновацій, застосування систем штучного інтелекту та врешті-решт зростання ВВП.

Ураховуючи складність поняття «урбанізація», що зумовлена насамперед причинами та наслідками цього явища, що проявляються у різних сферах життєдіяльності людини і відповідно мають бути враховані з позицій різних галузей державного управління, формування понятійно-категоріального апарату у сфері урбанізації $\epsilon$, на сьогодні, актуальним питанням. Відсутність єдиного підходу серед вчених щодо трактування категорії «урбанізація» зумовлено відмінністю предмета їх наукових досліджень.

Аналіз останніх досліджень та публікації, на які спирається автор. Проблемні питання урбанізації порушували у своїх наукових працях зарубіжні та вітчизняні автори, серед яких: М.Ф. Аверкина, Є.Н. Перцик, О.П. Зімовіна, А.С. Буряченко, Д.М. Кузьменко, І.В. Гукалова, Н.В. Омельченко, Ю.Л. Півоваров, В.В. Засадко, С.О. Ковальов, Я.Н. Ковальська, С.Таколи, Дж.МакГранахан, Д.Саттертуейт, Ю.А. Смагін, Я.Г. Машбіца, Т.Б. Заставецький та інші. Віддаючи належне науковим напрацюванням у даній сфері, слід вказати про необхідність вивчення підходів до визначення урбанізації з позицій системи публічного управління та адміністрування. 
Метою статті є вивчення підходів до визначення поняття «урбанізація», виявлення основних ознак, особливостей та характеристик цього явища задля уточнення понятійно-категоріального апарату у даній сфері, що, в свою чергу, у перспективі стане основою розробки теоретико-методологічних засад публічного управління наслідками урбанізації у відповідній сфері суспільного розвитку.

Викладення основного матеріалу. На початку ХХ ст. у світі було приблизно 360 великих міст. Під кінець їх чисельність становила близько 2500. Сьогодні це число досягає 4000. Раніше до великих міст належали міста 3 чисельністю населення понад 100 тис. жителів. Зазвичай сьогодні до великих міст зараховують міста-мільйонери, тобто з чисельністю населення понад 1 млн жителів. В Свропі таких міст чимало. Серед них варто вирізнити Лондон, Берлін, Мадрид, Рим та інші. Дана тенденція стала можлива через розвиток науково-технічного прогресу, зростання ролі науки в розвитку виробництва, підвищення загального рівня освіти, розвитку невиробничої сфери.

Вперше термін «урбанізація» був використаний у 1967 році в Іспанії. Урбанізацією позначали процеси, які були пов'язані з розростанням міських поселень, збільшенням кількості міст та зростанням міського населення [2].

На сьогоднішній день поняття «урбанізація»є значно ширшим і не може трактуватися лише як збільшення кількості міського населення.

Вважаємо за необхідне дослідити підходи щодо визначення поняття «урбанізація», що зазначають у своїх наукових працях вітчизняні та зарубіжні дослідники. Проаналізувавши праці науковців, було встановлено, що термін «урбанізація» розглядають як соціально-економічне явище, глобальний процес, процес підвищення значущості міст у житті суспільства, сукупність складних різноманітних процесів, пов'язаних зі зростанням і розвитком міст, збільшення частки населення, що проживає в міських районах, вплив міст на спосіб життя людей (табл. 1).

Таблиия 1

Підходи до визначення поняття «урбанізація», щзо наведені у наукових прачях зарубіжних та вітчизняних вчених

\begin{tabular}{|c|c|c|c|c|c|}
\hline \multirow[b]{2}{*}{ Автор, джерело } & \multicolumn{5}{|c|}{ Підходи до визначення поняття «урбанізація» } \\
\hline & $\begin{array}{c}\text { глобальний } \\
\text { процес }\end{array}$ & $\begin{array}{c}\text { процес } \\
\text { підвищення } \\
\text { значущості } \\
\text { міст у житті } \\
\text { суспільства }\end{array}$ & $\begin{array}{c}\text { процеси, } \\
\text { пов'язані зі } \\
\text { зростанням і } \\
\text { розвитком } \\
\text { міст }\end{array}$ & $\begin{array}{c}\text { збільшення } \\
\text { частки } \\
\text { населення, що } \\
\text { проживає в } \\
\text { містах }\end{array}$ & $\begin{array}{c}\text { вплив міст на } \\
\text { спосіб життя } \\
\text { людей }\end{array}$ \\
\hline Є.Н. Перцик [12] & + & + & - & - & - \\
\hline О.П. Зімовина [9] & + & - & - & - & - \\
\hline $\begin{array}{c}\text { А.С. Буряченко } \\
{[3, \text { с. } 87] .}\end{array}$ & + & - & + & - & - \\
\hline $\begin{array}{c}\text { Д.М. Кузьменко } \\
{[11]}\end{array}$ & + & - & - & - & + \\
\hline $\begin{array}{c}\text { І.В. Гукалова, } \\
\text { Н.В. Омельченко } \\
{[5, \text { с. } 104]}\end{array}$ & - & + & - & + & - \\
\hline $\begin{array}{c}\text { Ю.Л. Півоваров } \\
{[13, \text { с. 16]. }}\end{array}$ & - & + & + & & - \\
\hline В.В. Засадко [7] & - & + & + & + & - \\
\hline Л.В. Шелудько [15] & - & + & - & - & - \\
\hline $\begin{array}{c}\text { С.О. Ковальов, } \\
\text { Н.Я. Ковальська } \\
{[10]}\end{array}$ & - & - & + & - & - \\
\hline М.Ф. Аверкина [1] & - & - & + & + & - \\
\hline $\begin{array}{c}\text { Дж.МакГранахан, } \\
\text { Д.Саттертуейт } \\
{[17]}\end{array}$ & - & - & - & + & - \\
\hline $\begin{array}{l}\text { Ю.А. Смагін } \\
{[14, \text { с. } 116]}\end{array}$ & - & - & - & + & - \\
\hline Я.Г. Машбіца [4] & - & - & - & + & - \\
\hline $\begin{array}{c}\text { Т.Б. Заставецький } \\
{[8]} \\
\end{array}$ & - & + & - & - & + \\
\hline М.Хуссейн [16] & - & + & - & + & - \\
\hline PA30M & 4 & 7 & 5 & 7 & 2 \\
\hline
\end{tabular}


Нами було проаналізовано 15 джерел та встановлено, що 7 з них визначають урбанізацію як процес підвищення значущості міст у житті суспільства. Ще 4 автори зазначають, що це глобальний процес. Більшість авторів уточнює, що урбанізація - це збільшення частки населення, що проживає у містах. Серед проаналізованих джерел 5 вважають, що урбанізацією є процеси, пов'язані зі зростанням і розвитком міст, а ще 2 стверджують, що урбанізація - це вплив міст на спосіб життя людей.

Можна зробити висновок, що більшість науковців трактують поняття «урбанізація» як процес зростання, розвитку та підвищення значущості міст у житті суспільства.

Перцик Є.Н. та Зімовіна О.П. вважають, що урбанізація є глобальним процесом, адже на сьогоднішній день існує глобальна тенденція до урбанізації.

Перцик Є.Н. стверджує, що урбанізація є багатогранним глобальним процесом, що охопив увесь світ, пов'язаним із посиленим у часи науково-технічної революції розвитком і концентрацією виробничих сил і форм соціального спілкування, підвищенням ролі міст та розповсюдженням міського стилю життя на всю мережу населених пунктів [12].

Зімовіна О.П. характеризує урбанізацію як однин з глобальних процесів сучасного світу. На сьогоднішній день практично всі країни зіштовхнулися з цим явищем у різних формах залежно від рівня соціально-економічного розвитку, географічної схильності і специфіки протікаючих демографічних процесів. Крім того, урбанізація являє собою багатосторонній процес, при вивченні якого важливим $є$ врахування різних аспектів [9].

Неможливо не погодитися 3 цим підходом, адже кожні 5 років кількість міського населення у світі збільшується, приблизно на 2 \%, що зумовлює глобальний характер урбанізації.

Деякі науковці, говорячи про урбанізацію, зазначають, що це певний етап розвитку суспільства або світу.

На думку А.С. Буряченко, «...урбанізація - це вельми складний процес, і його не можна трактувати лише як зростання міст і збільшення чисельності міського населення. ... дане явище треба розуміти як новий етап розвитку суспільства, який характеризується концентрацією економічного, демографічного та політичного потенціалу, що дає змогу концентрувати та контролювати значні обсяги фінансових ресурсів, створювати нові технології, нові види послуг, здійснювати інноваційну діяльність» [3, с. 87].

Кузьменко Д.М. стверджує, що «урбанізацію розглядають як позитивну тенденцію розвитку світу, як об'єктивний процес, пов'язаний із забезпеченням для все більшої кількості жителів планети умов для більш зручного, комфортабельного, здорового життя, для більш повного розвитку здібностей. Урбанізація супроводжується не тільки позитивними змінами в житті людей, але й негативними, зокрема забрудненням навколишнього середовища, перенаселенням території, збільшенням негативних суспільних явищ» [11].

Більшість науковців дотримуються підходу, згідно з яким урбанізація $є$ процесом підвищення значущості міст у житті суспільства. Зокрема, І.В Гукалова. та Н.В. Омельченко вважають, що «урбанізація - це всебічний процес підвищення значущості міст у житті суспільства, результатом якого $є$ відносне збільшення міського населення і формування ієрархічної системи міських поселень як центрів поширення міських способу, умов життя населення і міської культури у конкретних суспільногеографічних умовах. При цьому міська культура - це дуже значущий компонент урбанізації, саме вона має свою специфіку на рівні типів країн, окремих країн та їх частин. Вона охоплює багато аспектів - від технологічних та економічних особливостей способу виробництва і способу життя до особливостей міського «ландшафту» [5, с. 104]. Півоваров Ю.Л., стверджує, що урбанізацією є історичний процес зростання ролі міст, міського способу життя і міської культури у розвитку суспільства, який пов'язаний із просторовою концепцією діяльності у порівняно нечисленних центрах і ареалах переважно соціальноекономічного розвитку [13, с. 16].

Засадко В.В. зазначає, що «урбанізацію слід розуміти не у вузькому розумінні як збільшення міст $\mathrm{i}$ міської людності, а як багатогранний соціально-економічний процес, який значно впливає на суспільні відносини. Так урбанізацією називають зростання і підвищення частки міського населення в країні, регіоні, світі. Таке тлумачення урбанізації є звуженим. У широкому розумінні слова - це світовий історичний процес підвищення ролі міст у житті суспільства, поступове перетворення його в міське за характером праці, способу життя, культури, що пов'язане із розвитком цивілізації, ходом науковотехнічного прогресу. Тобто головна ознака урбанізації - зростання міст, збільшення їх впливу на розселення та відповідне ускладнення їх функцій» [7].

Такий підхід користується найбільшою популярністю серед науковців. Суспільне життя людства нерозривно зв'язане 3 містом, адже кожна друга людина там мешкає. Сучасне місто є центром несільськогосподарського виробництва, постійно розширює свій вплив на навколишню територію і далі розвиває функції суспільно-політичного і культурного характеру.

Ковальов С.О., Ковальська Н.Я., Аверкина М.Ф. визначають урбанізацію як сукупність складних різноманітних процесів, пов'язаних зі зростанням і розвитком міст. 
Ковальов С.О. і Ковальська Н.Я. вважають, що урбанізація - це «сукупність складних різноманітних процесів, пов'язаних зі зростанням і розвитком міст. Ним позначають різні явища, які належать безпосередньо до процесів виникнення і формування самих міст і процесів, супроводжуючих виникнення міст чи побічно пов'язаних з ними, це сукупність процесів, які можуть не збігатися в часі і просторі. Вони охоплюють усі сфери життя і діяльності суспільства, а не тільки одне так зване урбанізоване середовище» [10].

Урбанізацію як соціально-економічне явище розглядала М.Ф. Аверкина, стверджуючи, що «урбанізація як соціально-економічне явище характеризується значним зростанням міст, міського населення, поширення міського способу життя на все суспільство» [1].

Шелудько Л.В. пише, що «урбанізація - це складний соціально-економічний процес, що проявляється у зростанні міських поселень, концентрації населення в них, особливо в великих містах і притаманного цьому міського стилю життя та зумовлює постійну модернізацію суспільства. Урбанізація сьогодні суперечливо поєднується з викликами, зумовленими необхідністю реалізації цілей, завдань та індикаторів продовольчої безпеки країн» [15].

Ряд науковців дотримується підходу, що урбанізація - це збільшення частки населення, що проживає в міських районах. Так Дж.МакГранахан і Д.Саттертуейт зазначають, що урбанізація визначається демографами як збільшення частки населення, що проживає в міських районах. Міські райони визначаються по-різному в різних країнах, але, як правило, міськими вважаються райони, які є більш щільно та густонаселеними, ніж сільські населені пункти, і є більш прийнятними для розміщення адміністративних об'єктів і виконання адміністративних функцій. Адміністративні та популяційні критерії взаємопов'язані, оскільки міський адміністративний статус, як правило, надається великим населеним пунктам [17].

Смагін Ю.А. пише, що урбанізація - «... це процес зростання чисельності міських поселень, в тому числі й крупних розмірів, концентрація населення в все більших крупних міських утвореннях, збільшення чисельності і частки міського населення» [14, с. 116].

Машбіца Я.Г. вважає, що процес урбанізації включає «зростання чисельності, питомої ваги i значення міського населення, розвиток міст різних типів і розмірів, формування систем і районних підсистем міських центрів» [4].

На нашу думку, даний підхід є дуже вузьким і неповним та не розкриває усієї суті поняття «урбанізація». На сьогоднішній день його не можна вважати вичерпним, оскільки він $є$ досить узагальненим і потребує уточнення.

Цікавою є думка Т.Б. Заставецького, який стверджує, що урбанізація - це процес, який виявляється не тільки в збільшенні частки міського населення та зростанні ролі міст у розвитку регіону, але й впливу міст на спосіб життя людей, їхню життєдіяльність, а також на існування всієї зони, прилеглої до міста $[8$, c. $41-45]$.

Погоджуємося з наведеним підходом до визначення, адже урбанізація не може не впливати на спосіб життя людей, тому що, по-перше, забезпечує зростання індустріальної промисловості та сфери послуг; по-друге, підвищує рівень освіченості і грамотності населення та, по-третє, збільшує відсоток населення, забезпеченого інфраструктурою.

Хуссейн М. у своїй статті зазначає, що урбанізація передбачає зміну економічних, соціальних та культурних аспектів суспільства. Це процес набуття міського стану, переміщення людей чи процесів у міські райони, збільшення міських територій, населення чи процес у соціальній еволюції людини [16].

Дослідивши підходи зарубіжних і вітчизняних науковців, встановлено, що сьогодні не існує єдиного підходу до визначення поняття «урбанізація». Така значна кількість підходів зумовлюється невизначеністю змісту та уніфікованістю цього поняття. Серед досліджених праць ідентифіковано підходи, які суперечать один одному щодо природи і сутності даного поняття.

Вважаємо, що урбанізацію доцільно визначати як глобальний процес, що характеризується підвищенням ролі міст у розвитку суспільства, який впливає на природне середовище, сільські поселення, розвиток країни, соціально-економічні відносини та спосіб життя людей.

Незважаючи на певні відмінності у трактуванні поняття «урбанізація», доцільно виокремити особливості сучасного процесу урбанізації.

Сучасна урбанізація характеризується:

1) швидкими темпами зростання міського населення;

2) розміщенням населення і господарства в основному у великих містах;

3) «розповзанням» міст, розширенням їх територій, тобто переходом від компактного міста до міських агломерацій і мегаполісів;

4) погіршенням екологічної ситуації в містах і промислових центрах.

У свою чергу, урбанізаційний процес можна поділити на стадії, характеристику яких подано у таблиці 2. 
Стадї розвитку урбанізаиії та їх характеристика

\begin{tabular}{|c|c|}
\hline $\begin{array}{c}\text { Стадія } \\
\text { розвитку } \\
\text { урбанізації }\end{array}$ & Характеристика урбанізації на визначеній стадії \\
\hline $\begin{array}{l}\text { Перша } \\
\text { стадія } \\
\text { розвитку }\end{array}$ & $\begin{array}{l}\text { На першій стадії міста виникають і розвиваються як окремі, локальні райони. } \\
\text { Зазвичай вони створювалися уздовж торгових маршрутів або на берегах річок. У міру } \\
\text { розвитку міста його організація стає все більш складною, з'являються проблеми, які } \\
\text { вимагають свого вирішення }\end{array}$ \\
\hline $\begin{array}{c}\text { Друга стадія } \\
\text { розвитку }\end{array}$ & $\begin{array}{l}\text { На другій стадії навколо точкових міст формуються агломерації. Більш дрібні } \\
\text { поселення стають супутниками великих міст, їх економіки починають 'міста або } \\
\text { навіть за його межами, починає їздити в центр для роботи, дозвілля, вирішення } \\
\text { побутових проблем }\end{array}$ \\
\hline $\begin{array}{c}\text { Третя стадія } \\
\text { розвитку }\end{array}$ & $\begin{array}{l}\text { На третій стадії урбанізації формується опорний каркас розселення. Відбувається } \\
\text { розосередження жителів на великому просторі. Каркас являє собою мережу, в якій як } \\
\text { вузли виступають сформовані міські поселення, пов’язані один з одним транспортними } \\
\text { артеріями (автомагістралями, залізницями тощо). Міста істотно впливають на } \\
\text { навколишню природу. У випадках, коли відбувається порушення екологічної рівноваги, } \\
\text { і негативні фактори урбанізації починають домінувати над позитивними, говорять про } \\
\text { явище гіперурбанізації. Вона характерна для розвинених країн }\end{array}$ \\
\hline
\end{tabular}

Україна належить до країн 3 високим рівнем урбанізації. Згідно 3 даними Державної служби статистики України [6], станом на 2019 рік міське населення становило 69,41 \%, а сільське - 30,59\%. В 1990 році міське населення становило 67,83 \%, а сільське населення - 32,17\%.

Соціальний та економічний розвиток України гальмується через те, що населення розміщується нерівномірно, що зумовлює наявність регресивних регіонів. Для них $є$ характерним слабкий рівень розвитку інфраструктури, що погіршує конкурентні переваги національних виробників, не тільки на зовнішніх, а й на внутрішніх ринках, скорочує радіус переміщення товарів і погіршує єдність економічного простору країни.

До найбільш урбанізованих областей України належать: Донецька, Луганська, Дніпропетровська, Харківська області, у них щільність населення сягає більше ніж 100 осіб/км², а рівень урбанізації дорівнює приблизно 90 \%. До неурбанізованих областей можна зарахувати території аграрної спеціалізації - Житомирську, Закарпатську, Кіровоградську та Херсонську. Щільність населення там не перевищує 50 осіб/км², а рівень урбанізації становить не більше $60 \%$.

Висновки та перспективи подальших досліджень. Результати вивчення підходів вітчизняних та зарубіжних вчених щодо визначення поняття «урбанізація», свідчать про неоднозначність трактування цієї категорії дослідниками. Серед проаналізованих джерел було ідентифіковано п'ять основних підходів, що використовують вчені, визначаючи сутність поняття «урбанізація», а саме: це визначення урбанізації як глобального процесу; як процесу підвищення значущості міст у житті суспільства; як процеси, пов’язані зі зростанням і розвитком міст; як збільшення частки населення, яке проживає в містах та як вплив міст на спосіб життя людей. Кількісний аналіз ідентифікованих та зазначених вище підходів щодо визначення вітчизняними та зарубіжними авторами сутності урбанізації, свідчить про розширення традиційного підходу визначення урбанізації як збільшення частки населення, що проживає у містах. Більшість авторів, що були проаналізовані у межах цього дослідження, схильні вважати, що це складне явище, яке характеризується зростанням, розвитком та підвищенням значущості міст у житті суспільства. 3 огляду на предмет даного дослідження, запропоновано під урбанізацією розуміти глобальний процес, що характеризується підвищенням ролі міст у розвитку суспільства, який впливає на природне середовище, сільські поселення, розвиток країни, соціально-економічні відносини та спосіб життя людей. Урбанізацію як складний процес, що взаємопов'язаний із суспільним розвитком, поділено та охарактеризовано з позицій відповідних стадій розвитку. Оцінка рівня урбанізованої територій України свідчить про нерівномірність поширення процесів урбанізації, а з огляду на те, що більшість регіонів характеризується низьким рівнем розвитку, дослідження даної проблематики є предметом подальших наукових розвідок. Пошук ефективних механізмів публічного управління та адміністрування, що враховують необхідність збалансування економічних, соціальних i екологічних чинників та передумов, а також застосування ефективного публічно-управлінського інструментарію задля ефективного використання потенціалу урбанізованих територій дозволяє досягти сталого економічного розвитку, ефективного використання земельних ділянок, оптимально поєднати розвиток великих, середніх і малих міст, забезпечити комплексний розвиток міст. 


\section{Список використаної літератури:}

1. Аверкина М.Ф. Вплив теорії стійкого розвитку міст на теорії урбаністики / М.Ф. Аверкина // Наукові записки Національного університету «Острозька академія». Серія : Економіка. - 2012. - Вип. 19. - С. 262266 [Електронний ресурс]. - Режим доступу : http://nbuv.gov.ua/UJRN/Nznuoa_2012_19_64.

2. Балуєва O.B. Урбанізаційні процеси: аналіз світових тенденцій / O.В. Балуєва // Економіка та держава. 2011. - № 6. - С. 53-56.

3. Буряченко A.C. Урбанізація в контексті фінансового, демографічного та соціального розвитку / А.Є. Буряченко // Вчені записки : зб. наук. праць ; редкол. : А.Ф. Павленко (відп. ред.) та ін. - Київ : КНЕУ, 2013. - Вип. 15. - 208 с.

4. Гукалова I.B. Якість життя населення України: суспільно-географічна концептуалізація / I.B. Гукалова. - К. : Ін-т географії Національної академії наук України, 2009. - 346 с.

5. Гукалова I.B. Категорія «урбанізація» у понятійній площині соціальної географії та інших наук / I.B. Гукалова, Н.В. Омельченко // Вісник Одеського національного університету. Серія : Географічні та геологічні науки. - 2015. - Т. 20, Вип. 2 (25). - 190 с.

6. Державна служба статистики України [Електронний pecypc]. - Режим доступу : http://www.ukrstat.gov.ua.

7. Засадко B.B. Роль урбанізації в контексті економічної безпеки та глобалізації: теоретичний зріз / B.B. Засадко // Науковий вісник Міжнародного гуманітарного університету. Серія : Економіка i менеджмент. - 2015. - Вип. 11. - С. 12-15 [Електронний ресурс]. - Режим доступу : http://nbuv.gov.ua/UJRN/Nvmgu_eim_2015_11_5.

8. Заставецький Т.Б. Система міських поселень агропромислового регіону в умовах трансформації суспільства : монографія / Т.Б. Заставецький. - Тернопіль, 2005. - 180 с.

9. Зимовина Е.П. Основные этапы формирования диаспоральной структуры Казахстана и стран Центральной Азии / Е.П. Зимовина [Электронный ресурс]. - Режим доступа : http://demoscope.ru/weekly/2009/0377/analit04.php.

10. Ковалев С.А. География населения СССР : учеб. пособие / С.А. Ковалев, Н.Я. Ковальская. - М., 1980. - 285 с.

11. Кузьменко Д.М. Дефініція поняття «урбанізація» в суспільній географії / Д.М. Кузьменко [Електронний peсурс]. - Режим доступу : http://dspace.univer.kharkov.ua/handle/123456789/7706.doc.

12. Перцик Е.Н. Геоурбанистика : учебник / Е.Н. Перцик. - М. : Академия, 2009. - 423 с.

13. Пивоваров Ю.Л. Основы геоурбанистики : учеб. пособие / Ю.Л. Пивоваров. - М. : Владос, 1999. - 232 с.

14. Смагин Ю.А. Территориальная организация населения : учеб. пособие / Ю.А. Смагин ; под общ. ред. В.Г. Глушковой. - 2-е изд., испр. и доп. - М. : Дашков и К., 2005. - 244 с.

15. Шелудько Л.В. Урбанізація як виклик продовольчій безпеці країни / Л.В. Шелудько // Економічний вісник університету. - 2018. - Вип. 39. - С. 121-128 [Електронний ресурс]. - Режим доступу : http://nbuv.gov.ua/UJRN/ecvu_2018_39_18.

16. Hussain M. Urbanization Concepts : dimensions and factors / M.Hussain, I.Imitiyaz, // Int J Recent Sci Res. 2018. - № 9 (1). - P. 23513-23523. - DOI: http://dx.doi.org/10.24327/ijrsr.2018.0901.1483.

17. McGranahan G. Urbanisation concepts and trends / G.McGranahan, D.Satterthwaite. - London : IIED Working Paper, 2014 [Electronic Resource]. - Access mode : http://pubs.iied.org/10709IIED.

\section{References:}

1. Averkyna, M.F. and Averkyna, M.F. (2012), «Vplyv teorii' stijkogo rozvytku mist na teorii' urbanistyky», Naukovi zapysky Nacional'nogo universytetu «Ostroz'ka akademija», Ser. Ekonomika, Issue. 19, pp. 262-266, [Online], available at: http://nbuv.gov.ua/UJRN/Nznuoa_2012_19_64

2. Balujeva, O.V. (2011), «Urbanizacijni procesy: analiz svitovyh tendencij», Ekonomika ta derzhava, No. 6, pp. 53-56.

3. Burjachenko, A.Je. (2013), «Urbanizacija v konteksti finansovogo, demografichnogo ta social'nogo rozvytku», Vcheni zapysky, in Pavlenko, A.F. (ed.), Issue 15, KNEU, Kyi'v, 208 p.

4. Gukalova, I.V. (2009), Jakist' zhyttja naselennja Ukrai'ny: suspil'no-geografichna konceptualizacija, In-t geografii' Nacional'noi' akademii' nauk Ukrai'ny, Kyi'v, 346 p.

5. Gukalova, I.V. and Omel'chenko, N.V. (2015), «Kategorija «urbanizacija» u ponjatijnij ploshhyni social'noi' geografii' ta inshyh nauk», Visnyk Odes'kogo nacional'nogo universytetu, Serija Geografichni ta geologichni nauky, Vol. 20, Issue 2 (25), 190 p.

6. Derzhavna sluzhba statystyky Ukrai'ny, [Online], available at: http://www.ukrstat.gov.ua

7. Zasadko, V.V. (2015), «Rol' urbanizacii' v konteksti ekonomichnoi' bezpeky ta globalizacii': teoretychnyj zriz», Naukovyj visnyk Mizhnarodnogo gumanitarnogo universytetu, Serija Ekonomika i menedzhment, Issue 11, pp. 1215, [Online], available at: http://nbuv.gov.ua/UJRN/Nvmgu_eim_2015_11_5

8. Zastavec'kyj, T.B. (2005), Systema mis'kyh poselen' agropromyslovogo regionu $v$ umovah transformacii' suspil'stva, Ternopil', $180 \mathrm{p}$.

9. Zimovina, E.P. (2009), Osnovnye jetapy formirovanija diasporal'noj struktury Kazahstana i stran Central'noj Azii, [Online], available at: http://demoscope.ru/weekly/2009/0377/analit04.php

10. Kovalev, S.A. and Koval'skaja, N.Ja. (1980), Geografija naselenija SSSR, Moskva, 285 p.

11. Kuz'menko, D.M., Definicija ponjattja «urbanizacija» $v$ suspil'nij geografii', [Online], available at: http://dspace.univer.kharkov.ua/handle/123456789/7706.doc

12. Percik, E.N. (2009), Geourbanistika, Akademija, Moskva, 423 p.

13. Pivovarov, Ju.L. (1999), Osnovy geourbanistiki, Vlados, Moskva, 232 p. 
14. Smagin, Ju.A. (2005), Territorial'naja organizacija naselenija, in Glushkovoj, V.G (ed), 2nd ed, Dashkov i K., Moskva, $244 \mathrm{p}$.

15. Shelud'ko, L.V. (2018), «Urbanizacija jak vyklyk prodovol'chij bezpeci krai'ny», Ekonomichnyj visnyk universytetu, Issue 39, pp. 121-128, [Online], available at: http://nbuv.gov.ua/UJRN/ecvu_2018_39_18

16. Hussain, M. and Imitiyaz, I. (2018), «Urbanization Concepts, Dimensions And Factors», Int J Recent Sci Res, No. 9 (1), pp. 23513-23523, DOI: http://dx.doi.org/10.24327/ijrsr.2018.0901.1483

17. McGranahan, G. and Satterthwaite, D. (2014), Urbanisation concepts and trends, IIED Working Paper, London, [Online], available at: http://pubs.iied.org/10709IIED

Сергієнко Лариса Василівна - кандидат наук з державного управління, доцент кафедри економічної безпеки, публічного управління та адміністрування Державного університету «Житомирська політехніка».

Наукові інтереси:

- механізми державного управління за галузями;

- державна економіко-екологічна політика.

Войціцька Катерина Миколаївна - аспірант, асистент кафедри економічної безпеки, публічного управління та адміністрування Державного університету «Житомирська політехніка».

Наукові інтереси:

- механізми державного управління урбанізаційними процесами;

- економічний розвиток урбанізованих територій.

Стаття надійшла до редакції 26.09.2019. 